\title{
International Society of Urological Pathology Gleason Grade Group
}

National Cancer Institute

\section{Source}

National Cancer Institute. International Society of Urological Pathology Gleason Grade

Group. NCI Thesaurus. Code C142346.

A grading system for prostatic adenocarcinoma based on modified Gleason cellular differentiation patterns and Gleason primary and secondary scores (Epstein Jl, Egevad L, Amin MB, Delahunt B, Srigley JR, Humphrey PA; Grading Committee. The 2014 International Society of Urological Pathology (ISUP) Consensus Conference on Gleason Grading of Prostatic Carcinoma: Definition of Grading Patterns and Proposal for a New Grading System. Am J Surg Pathol. 2016 Feb;40(2):244-52.) 